\title{
O IMPACTO DO DISCURSO RELIGIOSO SOBRE A SEXUALIDADE NO DIREITO DE FAMÍLIA
}

\author{
Matheus Rodrigues dos Santos Silva ${ }^{1}$ \\ Nilde Ferreira Balcão²
}

Resumo: A repressão à sexualidade foi responsável por estabelecer o modelo de família patriarcal e heterossexual. Entretanto, os casais homoafetivos buscam inserir-se no Direito como unidades familiares baseadas no afeto. O objetivo deste trabalho é analisar o conflito de concepções de família em sua positivação legal. Para isso, compara as definições do papel e das funções da família nos projetos de lei apresentados ao Congresso pela Frente Parlamentar Evangélica (FPE) que negam a diversidade das experiências sexuais com as decisões do STF e do CNJ favoráveis ao casamento homoafetivo. Busca-se apoio na historiografia para situar na história cultural do país a moral religiosa sobre a família e a sexualidade. Analisa as decisões judiciais à luz da Teoria Tridimensional do Direito, que permite considerar como fato social a unidade familiar formada por pessoas do mesmo sexo. Conclui-se que a FPE busca a retomada do modelo tradicional, utilizando-se de práticas discursivas que remontam às falas dos padres coloniais. Por outro lado, o modelo do afeto surge dos fatos da sociedade e da atuação do Judiciário.

Palavras-chave: Diversidade sexual; Direito de Família; Discurso religioso; Direitos humanos das minorias; Teoria Tridimensional do Direito.

\footnotetext{
${ }^{1}$ Direito/Universidade de Taubaté, Brasil. E-mail: matheus.rodss@gmail.com.

2 Sociologia/Universidade de Taubaté, Brasil. E-mail: nildebalcao@gmail.com.
} 